\title{
Reasons for success and lessons learnt from nanoscale vaccines against COVID-19
}

\begin{abstract}
Almost all currently used vaccines against COVID-19 consist of either non-viral or viral nanoparticles. Here we attempt to understand the reasons behind the success of such advanced nanoscale vaccine technologies compared with clinically established conventional vaccines, and the lessons to be learnt from this potentially transformative development in the adoption and acceptance of nanotechnology for medicine.
\end{abstract}

\section{Thomas Kisby, Açelya Yilmazer and Kostas Kostarelos}

$\mathrm{T}$ he outbreak of a novel coronavirus $(\mathrm{CoV})$ causing severe acute respiratory syndrome (SARS) was initially identified in China in late 2019 and rapidly developed into a global pandemic with devastating health and economic consequences $^{1}$. Driven by this, concerted effort by hundreds of laboratories across the world has led to the most rapid vaccine development in history, with clinical trials of promising candidates completed within a few months of the virus genome being reported ${ }^{2,3}$. Surprisingly, established vaccine technologies such as those based on inactivated/attenuated virions (entire virus particles) or on viral protein fragments, which have traditionally led the way in terms of clinical presence, market share and regulatory approval, have been clearly outplayed in both speed and immunoprotective efficacy by highly innovative technologies with no prior approved clinical use ${ }^{4}$. Even more remarkable is that most of these vaccine candidates rely on either synthetic or naturally occurring nanoscale vector systems (Table 1), with almost all of the candidates falling within the nanoscale size range (Fig. 1).

The current scale of administration and therefore exposure to non-viral or viral nanoparticles constitutes an unprecedented phenomenon of historic proportions and implications. The immediate reaction, even by some members of the scientific community, has been to acclaim nanoscience and nanomedicine as 'saviours' of humankind. However, what should be emphasized is that the successful implementation and mass

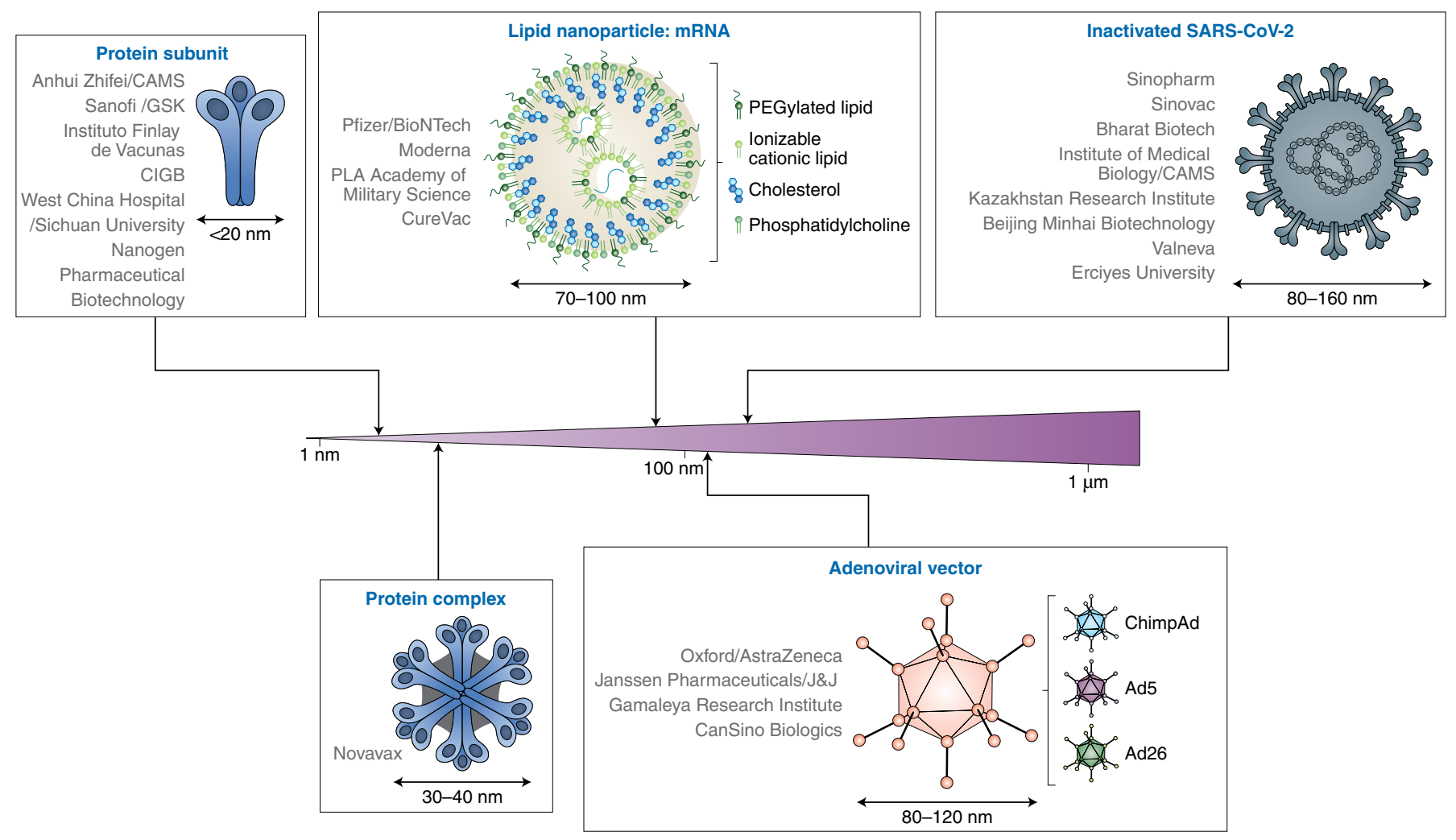

Fig. 1 | Nanoscale COVID-19 vaccines and institutions. The figure shows the nanoscale COVID-19 vaccines authorized for emergency clinical use or in Phase III active trials (up to July 2021) and the institutions that have developed and/or market them. 
Box 1 | Lessons learnt and challenges remaining for mRNA-LNP vaccines.

Lessons learnt
- Tolerable and efficacious mRNA
delivery system based on optimized
lipid formulations derived from
decades of liposome research
- Robust effectiveness of mRNA-LNP
vaccine systems
- Versatility of the mRNA vaccination
platform with fairly 'universal' LNP
delivery systems

Challenges remaining

- Thermal instability of mRNA cargo and associated logistical issues with maintenance and distribution

- Further optimization of the nanoscale delivery platform is required, to be most appropriate for the site(s) of administration; to produce target-specific immunoactivation; and to prolong the duration of the effect

- Achieving a 'one-shot' approach

- Cost is a roadblock for low- to middle-income countries, and leads to market competition with similarly effective but cheaper alternatives

- Unclear longevity and type of immunoprotection offered

- Hypersensitivity reactions rollouts of nanoscale vaccines we are now seeing are the result of years of research and product optimization that should certainly be celebrated, with investment in the area maintained. On the other hand, we believe that shallow glorification of nanomedicine should be avoided, and that consideration, caution and retrospective thinking should prevail, as we move forward epidemiologically in managing the pandemic.

\section{Engineering nanoscale vaccines}

To understand why 'nano' worked in this case, let us look at the nanoscale nature of the vector technologies that make the COVID-19 vaccines efficacious. For each of the three vaccine types currently being mass-administered to human populations (the non-viral mRNA-lipid nanoscale complex vaccines from Pfizer/BioNTech and Moderna; the genetically engineered viral nanoscale vaccines from AstraZeneca/ Oxford, Janssen/J\&J, Gamaleya and CanSino; and the conventional vaccines based on inactivated coronavirus from Sinopharm and Sinovac), we highlight the main lessons learnt from their extraordinarily rapid deployment and the challenges that remain (Boxes 1-3).

The case of mRNA-LNP complexes. The first COVID-19 vaccines to reach clinical testing and subsequent approval (initially by the Medicines and Healthcare Products Regulatory Agency (MHRA) in the United Kingdom) were the non-viral complexes based on lipid nanoparticle (LNP)-encapsulated mRNA encoding some form of the SARS-CoV-2 spike protein (Moderna) or its receptor binding domain (Pfizer/BioNTech) ${ }^{2,3,5}$. Despite no mRNA-based vaccines being previously approved for any pathology, the high efficacy (90-95\%) against SARS-CoV-2 infection in Phase III clinical trials led the MHRA, the US Food and Drug Administration (FDA) and the European Medicines Agency (EMA) to approve the vaccines for emergency use in late $2020^{6,7}$. While Pfizer/BioNTech and Moderna lead the way on this front, several alternative mRNA or self-replicating RNA-based vaccines are also in the clinical pipeline (Table 1). The mRNA itself is responsible for producing the active immunogen; and the design of this sequence to best mimic native antigen conformation, combined with advancements in nucleic acid engineering to maximize translation ${ }^{8}$, is fundamental to the success of this approach. However, without a nanoscale transport system to enable protected translocation of the mRNA across the plasma membrane and into the cytosol, it is doubtful whether enough mRNA molecules would provide the high levels of expression needed for immunogenic efficacy.

Both Pfizer/BioNTech and Moderna encapsulate their mRNA cargo inside an LNP. The use of LNPs to deliver nucleic acids intracellularly is not a new technology. Many investigators and commercial entities (mainly active in the gene therapy field) have explored preclinical and clinical applications of this technology, with evidence of clinical success, culminating in the recent approval of Onpattro ${ }^{9,10}$. Decades of research, including cellular mechanistic studies alongside advances in lipid synthesis, biochemistry and liposome science, have been undertaken to engineer LNPs from their beginnings as delivery systems for small molecules and proteins, through a lot of rational design optimization needed for effective intracellular transport of larger nucleic acids (such as mRNA).
Most of the mRNA vaccines against COVID-19 have been based on swift adaptation of existing nanoscale complexes for small interfering RNA (siRNA) therapeutics or mRNA vaccines for other diseases ${ }^{9,10}$. These were originally designed for intravenous administration, and aspects of their formulations have largely been carried over ${ }^{11,12}$. For example, the inclusion of polyethylene glycol (PEG), which has been well studied in liposomal drug delivery, with the ability to colloidally stabilize nanoparticles and provide a hydrophilic steric layer, plays a pharmacological role in prolonging blood circulation following systemic administration $^{13,14}$. Although PEG can offer enhanced stability of the nanoparticle systems, the instability of the mRNA cargo in the case of the Pfizer/BioNTech and Moderna COVID vaccines means that these still have to be stored and transported at ultra-low temperatures. There are various socioeconomic factors to be considered, and there are difficulties in transporting and storing non-thermostable vaccine formulations, especially for low-income countries ${ }^{15}$. Engineering the nanoscale transport systems further to improve the overall thermostability of the complex, while also optimizing for the appropriate route of administration, may improve effectiveness or longevity of immunoprotection, aid the usage of these highly efficacious vaccines in the developing world, and allow the design and clinical application of vaccine platforms against more complex pathophysiological conditions, such as cancer or neurodegeneration.

The case of adenoviruses. The non-viral mRNA complexes presented above were developed more rapidly and with higher reported efficacies than genetically modified viral nanoparticle-based vaccines. This is remarkable, as it is the first time since the late 1980s (when research on therapeutic genetic technologies began) that a non-viral nucleic acid vector system has been equivalent to, if not more efficacious than viral vectors for any clinical application.

The only approved viral vector COVID-19 vaccines currently in mass vaccination roll-outs are based on adenovirus. Adenoviruses are naturally occurring nanoscale objects (perfectly shaped, regular icosahedron nanoparticles that range in diameter between 90 and $100 \mathrm{~nm}$ ) with a long and tumultuous history of successes and failures in a wide variety of gene therapy applications ${ }^{16}$. The recognition of adenoviruses as nanoparticles 
Box 2 | Lessons learnt and challenges remaining for viral vaccines.

\begin{tabular}{|c|c|}
\hline Lessons learnt & Challenges remaining \\
\hline $\begin{array}{l}\text { - Adenovirus particles lie firmly within } \\
\text { the nanoscale and can be engineered } \\
\text { as such } \\
\text { - Adenoviral vaccine vectors provide } \\
\text { an effective platform with inherent } \\
\text { immunogenicity for vaccination } \\
\text { - Thermostability of such vectors } \\
\text { offers advantages over mRNA } \\
\text { systems }\end{array}$ & $\begin{array}{l}\text { - Humoral and adverse reactions can be more severe for } \\
\text { adenoviral vectors } \\
\text { - Potential inactivation due to existing or acquired immunity } \\
\text { - Repeat dosing or booster vaccination regimes of } \\
\text { adenoviral vectors can be of higher risk } \\
\text { - Optimization for 'single shot' } \\
\text { - Undefined levels, types and duration of immunity offered } \\
\text { from different adenovirus serotypes (Ad5, Ad26, Ad35) } \\
\text { used } \\
\text { - Rare blood-clotting events }{ }^{\star} \text { in subsets of vaccinated } \\
\text { individuals }\end{array}$ \\
\hline
\end{tabular}

*Based on currently available literature and published studies, the evidence on the role of platelets in these rare adverse effects (whether low platelets are the cause and not an effect) is not yet clear.

of biological nature has allowed their surface and structural engineering at the nanoscale, leading to re-designed vectors with versatile capabilities ${ }^{17}$. All of the currently authorized COVID-19 adenovirus-based vaccines are based on a typical adenoviral nanoparticle, genetically modified to replace their key codons for replication (E1/E3) with DNA sequences encoding for a version of the SARS-CoV-2 spike protein (or its receptor binding domain). However, key differences exist in their design. The Oxford/AstraZeneca vaccine (ChAdOx1 nCoV-19) comprises a novel chimp adenovirus (ChAd) to overcome potential pre-existing anti-vector immunity ${ }^{18}$, whereas the Gamaleya Research Institute vaccine (Sputnik-V) uses a heterologous prime-boost approach where the first dose is provided in a human type- 26 adenovirus (Ad26), followed by a traditional human type-5 (Ad5) second dose to overcome any anti-vector immunity generated by the first dose $\mathrm{e}^{19}$. The only previous case of an approved adenovirus-based vaccine is the Ad26-based Ebola vaccine approved in 2019, which of course did not have the current widespread use $\mathrm{e}^{20}$.

Most of the vaccines developed against COVID-19 require a two-dose administration regimen. There are various potential complications of this, including the higher risk of anaphylactic or adverse reactions during one of the injections, and obviously the cost and inconvenience to health systems. There seems to be a tendency to overcome most of these challenges in the adenovirus vector vaccine space by approvals of single-dose vaccinations. Janssen/J\&J obtained authorization for emergency use of their vaccine as a single administration across the United States, United Kingdom and European Union, reporting an efficacy of around $60-85 \%$ prevention of moderate to severe disease ${ }^{21}$. Similarly, the CanSino adenovirus-based vaccine aims toward a single-shot approach, with their Phase II trial reporting robust immunogenicity ${ }^{22}$. The Oxford/AstraZeneca vaccine also has demonstrated single-dose effectiveness ${ }^{23}$. There remain unanswered questions as to why the 'single-shot' approach was not preferred in the first place, whether consecutive doses offer further significant levels of protection, and whether the 'two-shot' approach provides longer-lasting immunity ${ }^{24}$. From the perspective of viral nanoparticle exposure, the scale of human exposure to adenovirus particles undertaken at the moment is unprecedented, so any nanotoxicological and immunotoxicological limitations will surely be unravelled. One such effect is the rare blood-clotting events reported within days from the administration of the authorized adenoviral vaccines (both AstraZeneca and Janssen/J\&J $)^{25,26}$. There is a need for mechanistic immunotoxicology to decipher the reasons behind such adverse effects.

Currently, at least five of the adenovirusbased vaccines developed against COVID-19 are using the Ad5 serotype as the DNA carrier (Table 1). Ad5 is ubiquitous in nature and infects humans frequently, leading to a very high prevalence of anti-Ad5 antibodies in populations worldwide, which in turn may jeopardize the efficacy of the vaccination ${ }^{27}$. However, even with the use of more novel serotypes with substantially less initial seroprevalence (Ad26, ChAd), there is the open question of whether the serotype-specific anti-adenovirus immune response generated by the first dose (or series of doses) will severely limit the effectiveness of a booster shot, or those designed against new vaccine-resistant variants, which may be required in the future. Nanoscience can play an important role in addressing this challenge by nanoscale engineering of the adenovirus surface capsid, using lipid or polymer molecular self-assembly and conjugation strategies ${ }^{28-32}$.

\section{The case of protein subunit and} inactivated coronaviruses. The clinical success and approval of both mRNA-LNP and adenovirus-based approaches demonstrate that synthetic, rationally designed or naturally occurring genetically engineered nanoparticle vector systems can work effectively and play a critical role in resolving the COVID pandemic. Of note, the peculiarity we have witnessed of nano-enabled approaches being first to market is scientifically supported by a number of failures in the conventional vaccine landscape (see abandoned trials in Table 1$)^{33-35}$. Despite varying reports of efficacy (ranging from $50 \%$ to $83 \%$ ), several more conventional vaccine technologies including inactivated SARS-CoV-2 and protein subunit approaches have now seen emergency authorization in at least one country (Table 1), with many others progressing through clinical development. As time progresses, and results from Phase III trials are released, clarity will emerge over whether these conventional approaches match the efficacy of the nanoscale mRNA-LNP and viral vector strategies. It will be particularly important to obtain credible and transparent data from the mass-vaccination programmes undertaken with these vaccines in different regions of China.

Nanoscale engineering and creativity is abundant in this vaccine category too. Conventional protein subunit vaccines have been modifed, for instance by generating virus-like protein complexes to enable better antigenpresenting-cell uptake and antigenicity. Novavax exploits this, with its recombinant nanoparticle vaccine (NVX-CoV2373), consisting of a spike protein complex with Matrix-M1 adjuvant, demonstrating high efficacy (up to $89 \%$ ) against a number of different SARS-CoV-2 variants ${ }^{36,37}$. This indicates that further refinement and modification of these conventional protein-based vaccine approaches could provide competitive strategies that also offer cost and manufacturing advantages over mRNA-LNP or viral vector systems.

Although mainly nanotechnologyenabled COVID-19 vaccines are currently approved for emergency use, it will 


\begin{tabular}{|c|c|}
\hline \multicolumn{2}{|c|}{$\begin{array}{l}\text { Box } 3 \text { | Lessons learnt and challenges remaining for protein subunit and inactivated } \\
\text { virus vaccines. }\end{array}$} \\
\hline Lessons learnt & Challenges remaining \\
\hline $\begin{array}{l}\text { - Existing conventional technologies can } \\
\text { be used as effective COVID-19 vaccines } \\
\text { - Speed of development of 'traditional' } \\
\text { vaccine technologies lags behind more } \\
\text { advanced vectors and technologies }\end{array}$ & $\begin{array}{l}\text { - Varying effectiveness reported in initial clinical } \\
\text { trial results } \\
\text { - Further optimization of antigen selection and } \\
\text { adjuvant is required to match efficacy of approved } \\
\text { vaccines } \\
\text { - Unclear whether traditional vaccine development } \\
\text { pipelines are able to rapidly redesign against new } \\
\text { viral mutants }\end{array}$ \\
\hline
\end{tabular}

be interesting to monitor, as more conventional approaches gain approval, whether the reduced cost, simplicity in manufacturing and logistical benefits will eventually lead these conventional vaccine types to take over clinical use worldwide, particularly if a repeat booster vaccination (annual or more frequent) is required to maintain immunity against spreading mutations ${ }^{38}$.

\section{Transient success or fruits of a mature field}

During the past year, and following the call to arms for nanoscience research at the beginning of the pandemic in Europe $^{39}$, advances in nanotechnology and nanomedicine have had an indisputably important impact. This is quite redemptive for a field that has recently gone through a phase of self-doubt and subsequent maturity, albeit mainly, and perhaps too narrowly, in relation to clinical translation of nanotechnologies in oncology $y^{40-42}$. Given the successful development, upscale manufacturing and launch in mass-vaccination programmes around the world of nanoscale lipid-based mRNA (non-viral) and nanosized adenovirus-based (viral) vaccines, there is the danger of triumphalism for nanomedicine. This is inappropriate and risks diminishing credibility for this thriving field.

\section{Reasons for nanoscience innovation to} win over conventional strategies. Both the non-viral and viral nanoscale vaccine vectors currently being injected into millions of people are technologies that previously had almost no (or, at best, 'niche') clinical presence. In that sense, they are innovative. But both vector platforms have undertaken at least a 25-year-long development pathway towards clinical translation in many different therapeutic approaches and disease indications. Both technologies have already gone through multiple cycles of successes, failures, near-misses and false starts, in the hands of multiple academic, clinical and industrial parties. We believe that this is the true reason behind their successful deployment with such speed and potency. The level of accumulated knowledge and creative work behind different aspects of those systems (chemically, molecularly, biologically and pharmacologically) is vast and did not start last year. It would certainly be naïve to think that lipid-based and adenovirus-based vector technology platforms have been an invention of the past few months.

\section{Nanomedicine success could be a} transient result of pandemic-driven opportunism. It is in the common interest that effective and safe COVID-19 vaccines should be rolled out in mass-population vaccination campaigns. The fact that established vaccine technologies take longer to develop and are much less effective in preventing severe disease and shielding against infection ${ }^{4,33}$ has offered the nanoscale lipid-based and adenovirus-based vaccine vectors an opportunity in terms of science and technology, but also in terms of market share. It is debatable continue to be used in population-wide vaccination programmes even after more conventional, established and cheaper vaccines (for example, those based on adjuvanted protein fragments) have been launched. The biological complexity and evolution of the prevalent coronavirus strains themselves will also determine the effectiveness and ease of engineering adaptability needed by future vaccines. There are still a few unknowns that could determine their longer-term use against COVID-19 in the future, such as (1) the duration of protection against infection; (2) the ease and flexibility of incorporating new sequences against new coronavirus mutants; (3) the simplification of manufacturing processes and logistics whether these nanoscale vaccines will in handling (maintenance, storage, stability); and (4) cost.

Traditional vaccines could achieve all of the above with reasonable protection and at a fraction of the cost, provided they are efficacious against and easy to adapt to new $\mathrm{CoV}$ variants. The innovative nanoscale vaccines currently used (primarily in the developed, western hemisphere) can result in overall economic benefits, provided they allow lifting of severe restrictions. However, it is hard to imagine how to overcome the high cost of manufacturing, maintenance and transport of thermolabile molecules (RNA, lipids) to vaccinate the developing world en masse. Considering that mRNALNP vaccines have been under clinical development (but not authorized for use before the pandemic) against various viruses including influenza viruses, rabies and Zika virus ${ }^{8}$, the safety and efficacy profile observed during the COVID-19 pandemic will certainly pave the way for these prophylactic vaccines as well. Also, it must be stressed that both non-viral and viral nanoscale vector technologies were originally developed with the intention to be used against more biologically complex pathological conditions and disease states, such as cancer. It will not be surprising if the mRNA-LNP (and to a less extent the adenovirus) vector systems return to re-focus on the development of vaccines for more complex (for example, cancer, neurological diseases) and rare diseases after the pandemic subsides.

Transformative impact on approval
and acceptance of new nanoscale
technologies for medicine. Humankind is
not familiar with using nanoscale
objects so widely. That may explain
the degree of unease from many in
accepting multiple injections of
nanoparticle-based vectors. It can also
lead to extreme views and conspiracy
theories (for example, wireless nanorobotic
chips contained in vaccines) that some
circles wish to propagate to serve their
own political agendas. That is why
caution, consideration, understanding
and accurate communication of the
scientific and clinical facts generated
from such an unprecedented and
intended exposure to nanoparticles
to the public are needed. Provided
that short- and long-term safety is not
compromised, the extent of nanoscale
vaccine deployment that we are witnessing
will surely have a marked impact on how
regulators, ethics review committees
and investors view nanoscience and
nanotechnology used in medicine.




\section{Table 1 | Overview of all COVID-19 vaccines currently under emergency-use authorization or clinical development}

\begin{tabular}{|c|c|c|c|c|c|c|c|c|c|c|}
\hline $\begin{array}{l}\text { Vaccine } \\
\text { vector type }\end{array}$ & $\begin{array}{l}\text { Clinical trial } \\
\text { phase }\end{array}$ & Developer(s) & Name & Biological agent (antigen) & $\begin{array}{l}\text { Nanoparticle/ } \\
\text { vector }\end{array}$ & Size (nm) & $\begin{array}{l}\text { Storage/ } \\
\text { transport }\end{array}$ & $\begin{array}{l}\text { Admin. } \\
\text { method }\end{array}$ & $\begin{array}{l}\text { No. of } \\
\text { doses }\end{array}$ & $\begin{array}{l}\text { Previous } \\
\text { clinical } \\
\text { use }\end{array}$ \\
\hline \multirow[t]{16}{*}{ mRNA-LNP } & In use III+ & Pfizer/BioNTech & BNT162b2 & $\begin{array}{l}\text { mRNA (stable perfusion } \\
\text { S protein) }\end{array}$ & LNP & $70-100$ & $\mathrm{~F}$ & $\mathrm{IM}$ & 2 & $\mathrm{n} / \mathrm{a}$ \\
\hline & In use III+ & $\begin{array}{l}\text { Moderna/National Institute of } \\
\text { Allergy and Infectious Diseases }\end{array}$ & mRNA-1273 & $\begin{array}{l}\text { mRNA (stable prefusion } \\
\mathrm{S}-2 \mathrm{P} \text { ) }\end{array}$ & LNP & $70-100$ & $\mathrm{~F}$ & IM & 2 & \\
\hline & III & CureVac & $\mathrm{CVnCoV}$ & mRNA (full S protein) & LNP & $70-100$ & $\mathrm{R} / \mathrm{F}$ & IM & 2 & \\
\hline & III & $\begin{array}{l}\text { PLA Academy of Military } \\
\text { Sciences/Walvax Bio/ } \\
\text { Suzhou Abogen }\end{array}$ & ARCoV & $\begin{array}{l}\text { mRNA (codon-optimized } \\
\text { RBD) }\end{array}$ & LNP & $70-100$ & $R$ & IM & 2 & \\
\hline & ॥ & Arcturus/Duke & ARCT-021/LUNAR-COV19 & srRNA (full S protein) & LNP & $70-100$ & $\mathrm{~L} / \mathrm{F}$ & IM & n.d. & \\
\hline & ॥ & $\begin{array}{l}\text { Moderna/National Institute } \\
\text { of Allergy and Infectious } \\
\text { Diseases }\end{array}$ & mRNA-1273.351 & $\begin{array}{l}\text { mRNA (stable prefusion } \\
\text { S-2P B.1.351 variant) }\end{array}$ & LNP & $70-100$ & $\mathrm{~F}$ & IM & $1-3$ & \\
\hline & I/II & Sanofi Pasteur/Translate Bio & MRT5500 & $\begin{array}{l}\text { mRNA (S-2P/GSAS } \\
\text { mutations) }\end{array}$ & LNP & $70-100$ & $\mathrm{~F}$ & IM & 2 & \\
\hline & $1 / 11$ & Daiichi Sankyo Co., Ltd. & DS-5670a & mRNA & LNP & $70-100$ & $\mathrm{~F}$ & IM & 2 & \\
\hline & $1 / I I$ & Elixirgen Therapeutics, Inc & EXG-5003 & ts-srRNA (RBD) & - & - & - & ID & 1 & \\
\hline & 1 & Chulalongkorn University & $\begin{array}{l}\text { ChulaCov19 mRNA } \\
\text { vaccine }\end{array}$ & mRNA (S protein) & LNP & $70-100$ & $\mathrm{R} / \mathrm{F}$ & $\mathrm{IM}$ & 2 & \\
\hline & । & Providence Therapeutics & PTX-COVID19-B & mRNA (S protein) & LNP & $70-100$ & $\mathrm{~F}$ & IM & 2 & \\
\hline & । & SENAI CIMATEC & HDT-301 & srRNA (full S protein) & LNP (inorganic) & $70-100$ & $\mathrm{R} / \mathrm{F}$ & $\mathrm{IM}$ & 2 & \\
\hline & । & Moderna & mRNA-1283 & mRNA (S protein RBD/NTD) & LNP & $70-100$ & $\mathrm{R}$ & IM & 2 & \\
\hline & 1 & GSK & CoV2 SAM & srRNA (S protein) & LNP & $70-100$ & $\mathrm{R} / \mathrm{F}$ & $\mathrm{IM}$ & 2 & \\
\hline & 1 & $\begin{array}{l}\text { Shanghai East Hospital/ } \\
\text { Stemirna Therapeutics }\end{array}$ & mRNACOVID-19 & mRNA & LNP & $70-100$ & - & $\mathrm{IM}$ & 2 & \\
\hline & $\mathrm{Ab}$ & Imperial College London & LNP-nCoVsaRNA & $\begin{array}{l}\text { srRNA (prefusion stabilized } \\
\text { S protein) }\end{array}$ & LNP & $70-100$ & $\mathrm{~F}$ & IM & 2 & \\
\hline DNA-LNP & । & Entos Pharmaceuticals & Covigenix VAX-001 & DNA (S protein) & PLV NP & $70-100$ & - & IM & 2 & $n / a$ \\
\hline \multirow{8}{*}{$\begin{array}{l}\text { Protein } \\
\text { complex/ } \\
\text { VLP }\end{array}$} & III & Novavax & NVX-CoV2373 & $\begin{array}{l}\text { Stabilized full length S } \\
\text { protein complex }\end{array}$ & $\begin{array}{l}\text { Protein/ } \\
\text { MatrixM NP }\end{array}$ & $30-40$ & $\mathrm{R}$ & $\mathrm{IM}$ & 2 & $\checkmark$ \\
\hline & II/III & Medicago & CoVLP & S protein & $\mathrm{pV} V \mathrm{P}$ & 100 & $\mathrm{R}$ & $\mathrm{IM}$ & 2 & \\
\hline & II & $\begin{array}{l}\text { The Scientific and Technological } \\
\text { Research Council of Turkey }\end{array}$ & SARS-CoV-2 VLP & 4 structural proteins & VLP & $100-120$ & - & SC & 2 & \\
\hline & I/II & SK Bioscience & GBP510 & RBD domain & Protein NP & $30-40$ & $R$ & IM & 2 & \\
\hline & $1 / I I$ & VBI Vaccines & VBI-2902 & S protein & eVLP & $90-200$ & $\mathrm{R} / \mathrm{RT}$ & IM & 2 & \\
\hline & $1 / I I$ & $\begin{array}{l}\text { SpyBiotech/Serum Institute } \\
\text { of India }\end{array}$ & $\begin{array}{l}\text { RBD SARS-CoV- } 2 \mathrm{HBsAg} \\
\text { VLP vaccine }\end{array}$ & $\mathrm{RBD}$ domain & VLP & $20-40$ & $\mathrm{R}$ & $\mathrm{IM}$ & 2 & \\
\hline & । & $\begin{array}{l}\text { Walter Reed Army Institute of } \\
\text { Research }\end{array}$ & SpFN & S protein & $\begin{array}{l}\text { Ferritin NP + } \\
\text { liposome }\end{array}$ & $30-100$ & - & IM & 3 & \\
\hline & । & Radboud University & ABNCoV2 & RBD domain & VLP & $30-60$ & $\mathrm{R}$ & IM & 2 & \\
\hline \multirow{12}{*}{$\begin{array}{l}\text { Viral vector/ } \\
\text { modified } \\
\text { virus }\end{array}$} & In use III+ & $\begin{array}{l}\text { University of Oxford/ } \\
\text { AstraZeneca }\end{array}$ & AZD1222 (ChAdOx1-S) & DNA (full S protein) & ChAd & $90-100$ & $\mathrm{R}$ & $\mathrm{IM}$ & 2 & $\sqrt{ } \#$ \\
\hline & In use III+ & $\begin{array}{l}\text { Janssen Pharmaceutical/ } \\
\text { Johnson \& Johnson }\end{array}$ & Ad26.COV2.S & DNA (full S protein) & Ad26 & $90-100$ & R & IM & 1 & \\
\hline & In use III+ & Gamaleya Research Institute & $\begin{array}{l}\text { Sputnik-V } \\
\text { (Gam-COVID-Vac) }\end{array}$ & DNA (full S protein) & Ad26/Ad5 & $90-100$ & $F / R /(L)$ & $\mathrm{IM}$ & 2 & \\
\hline & In use III+ & $\begin{array}{l}\text { CanSino/Beijing Institute of } \\
\text { Biotechnology }\end{array}$ & Ad5-nCoV & DNA (full S protein) & Ad5 & $90-100$ & $R$ & IM & 1 & \\
\hline & II/III & ReiThera/Leukocare/Univercells & GRAd-COV2 & DNA (full S protein) & GrAd & $90-100$ & $\mathrm{R}$ & $\mathrm{IM}$ & 1 & \\
\hline & $1 / I I$ & Cellid & AdCLD-CoV19 & DNA (full S protein) & Ad5/35 & $90-100$ & $\mathrm{R}$ & $\mathrm{IM}$ & 1 & \\
\hline & $1 / I I$ & ImmunityBio/NantKwest & $\begin{array}{l}\text { hAd5-S-Fusion+N-ETSD } \\
\text { vaccine }\end{array}$ & DNA (S and N proteins) & Ad5 & $90-100$ & $\mathrm{RT} / \mathrm{R}$ & SC/oral & 2 & \\
\hline & 1 & Vaxart & VXA-CoV2-1 & DNA ( $S$ and $N$ proteins) & Ad5 & $90-100$ & RT & Oral & 2 & \\
\hline & 1 & $\begin{array}{l}\text { Tetherex Pharmaceuticals } \\
\text { Corporation }\end{array}$ & $\begin{array}{l}\text { SC-Ad6-1 (single cycle } \\
\text { replicating) }\end{array}$ & DNA (S protein) & Ad6 & $90-100$ & $\mathrm{R}$ & $\mathrm{IM}$ & n.d. & \\
\hline & । & Bharat Biotech & BBV154 & DNA (full S protein) & ChAd & $90-100$ & $\mathrm{R}$ & IN & $1-2$ & \\
\hline & । & Gritstone Oncology & ChAd/SAM Prime Boost & $\begin{array}{l}\text { DNA + srRNA (S protein + } \\
\text { additional epitopes) }\end{array}$ & ChAd + LNP & $90-100$ & - & IM & $2-3$ & \\
\hline & $1 / I I$ & $\begin{array}{l}\text { Institute of Vaccines and } \\
\text { Medical Biologicals }\end{array}$ & COVIVAC & RNA (S protein)/S protein & NDV & $150-400$ & $\mathrm{R}$ & $\mathrm{IM}$ & 2 & $n / a$ \\
\hline
\end{tabular}




\section{Table 1 | Overview of all COVID-19 vaccines currently under emergency-use authorization or clinical development (Continued)}

\begin{tabular}{|c|c|c|c|c|c|c|c|c|c|c|}
\hline $\begin{array}{l}\text { Vaccine } \\
\text { vector type }\end{array}$ & $\begin{array}{l}\text { Clinical trial } \\
\text { phase }\end{array}$ & Developer(s) & Name & Biological agent (antigen) & $\begin{array}{l}\text { Nanoparticle/ } \\
\text { vector }\end{array}$ & Size (nm) & $\begin{array}{l}\text { Storage/ } \\
\text { transport }\end{array}$ & $\begin{array}{l}\text { Admin. } \\
\text { method }\end{array}$ & $\begin{array}{l}\text { No. of } \\
\text { doses }\end{array}$ & $\begin{array}{l}\text { Previous } \\
\text { clinical } \\
\text { use }\end{array}$ \\
\hline & I/II & $\begin{array}{l}\text { Mahidol/Icahn School of } \\
\text { Medicine/Government } \\
\text { Pharmaceutical Org }\end{array}$ & NDV-HXP-S & $\begin{array}{l}\text { RNA (S-F protein)/ } \\
\text { S-F protein }\end{array}$ & NDV & $150-400$ & $\mathrm{R}$ & IM & 2 & \\
\hline & I & Laboratorio Avi-Mex & Patria & RNA (S protein)/S protein & NDV & $150-400$ & $\mathrm{R}$ & $\mathrm{IM} / \mathrm{IN}$ & 2 & \\
\hline & I/II & $\begin{array}{l}\text { Israel Institute for Biological } \\
\text { Research }\end{array}$ & rVSV-SARS-COV-2-S & RNA (S protein)/S protein & VSV & $70-200$ & $\mathrm{~F}$ & $\mathrm{IM}$ & 1 & $\checkmark$ \\
\hline & I & $\begin{array}{l}\text { City of Hope/National Cancer } \\
\text { Institute }\end{array}$ & $\begin{array}{l}\text { COHO4S1 } \\
\text { (MVA-SARS-2-S) }\end{array}$ & DNA (S and N proteins) & MVA & $250-310$ & $\mathrm{~F}$ & IM & 2 & $\checkmark$ \\
\hline & 1 & $\begin{array}{l}\text { Ludwig-Maximilians/University } \\
\text { of Munich }\end{array}$ & MVA-SARS-2-S & DNA (full S protein) & MVA & $250-310$ & - & IM & 2 & \\
\hline & $A b$ & Altimmune & AdCOVID & DNA (RBD of $S$ protein) & Ad5 & $90-100$ & $\mathrm{R}$ & IN & 1 & \\
\hline & $A b$ & $\begin{array}{l}\text { Merck/Institute Pasteur/ } \\
\text { University of Pittsburgh }\end{array}$ & V591-001/TMV-o38 & RNA (S protein) & MV & $150-250$ & - & $\mathrm{IM}$ & 2 & $\checkmark$ \\
\hline \multirow{3}{*}{$\begin{array}{l}\text { Live } \\
\text { attenuated } \\
\text { virus }\end{array}$} & ॥ & $\begin{array}{l}\text { Hong Kong/Beijing Wantai } \\
\text { Biological Pharmacy/Xiamen }\end{array}$ & $\begin{array}{l}\text { DelNS1- } \\
\text { 2019-nCoV-RBD-OPT1 }\end{array}$ & RNA (RBD domain) & InfluenzaV & $80-120$ & $\mathrm{R}$ & IN & 2 & $\checkmark$ \\
\hline & 1 & $\begin{array}{l}\text { Codagenix/Serum Institute } \\
\text { of India }\end{array}$ & COVI-VAC & $\begin{array}{l}\text { Live attenuated } \\
\text { SARS-CoV-2 }\end{array}$ & & $80-160$ & $R$ & IN & $1-2$ & \\
\hline & I & Meissa Vaccines, Inc. & MV-014-212 & RNA (S protein)/S protein & RSV & $150-250$ & - & IN & $1-2$ & \\
\hline \multirow[t]{14}{*}{$\begin{array}{l}\text { Inactivated } \\
\text { virus }\end{array}$} & In use III+ & $\begin{array}{l}\text { Sinopharm/Beijing Institute of } \\
\text { Biological Products }\end{array}$ & BBIBP-CorV & Inactivated SARS-CoV-2 & & $80-160$ & $\mathrm{R}$ & IM & 2 & $\checkmark$ \\
\hline & In use III+ & $\begin{array}{l}\text { Sinovac Research and } \\
\text { Development }\end{array}$ & CoronaVac & Inactivated SARS-CoV-2 & & $80-160$ & $\mathrm{R}$ & $\mathrm{IM}$ & 2 & \\
\hline & In use III+ & $\begin{array}{l}\text { Sinopharm/Wuhan Institute of } \\
\text { Biological Products }\end{array}$ & $\begin{array}{l}\text { Inactivated SARS-CoV-2 } \\
\text { vaccine }\end{array}$ & Inactivated SARS-CoV-2 & & $80-160$ & $\mathrm{R}$ & $\mathrm{IM}$ & 2 & \\
\hline & In use III+ & Bharat Biotech & BBV152 & Inactivated SARS-CoV-2 & & $80-160$ & $\mathrm{R}$ & IM & 2 & \\
\hline & In use III+ & $\begin{array}{l}\text { Kazakhstan Research Institute } \\
\text { for Biological Safety }\end{array}$ & QazCovid-in & Inactivated SARS-CoV-2 & & $80-160$ & $\mathrm{R}$ & IM & 2 & \\
\hline & In use III+ & Beijing Minhai Biotechnology & SARS-CoV-2 Vaccine & Inactivated SARS-CoV-2 & & $80-160$ & $\mathrm{R}$ & IM & 2 & \\
\hline & III & $\begin{array}{l}\text { Institute of Medical Biology/ } \\
\text { Chinese Academy of Medical } \\
\text { Sciences }\end{array}$ & SARS-CoV-2 vaccine & Inactivated SARS-CoV-2 & & $80-160$ & $\mathrm{R}$ & IM & 2 & \\
\hline & III & Valneva & VLA2001 & Inactivated SARS-CoV-2 & & $80-160$ & $\mathrm{R}$ & IM & 2 & \\
\hline & III & Erciyes University & ERUCOV-VAC & Inactivated SARS-CoV-2 & & $80-160$ & $\mathrm{R}$ & IM & 2 & \\
\hline & $\|/\| I I$ & Shifa Pharmed Industrial & $\begin{array}{l}\text { COVID-19 inactivated } \\
\text { virus }\end{array}$ & Inactivated SARS-CoV-2 & & $80-160$ & $\mathrm{R}$ & IM & 2 & \\
\hline & I/II & KM Biologics Co & $\begin{array}{l}\text { Inactivated COVID-19 } \\
\text { vaccine }\end{array}$ & Inactivated SARS-CoV-2 & & $80-160$ & $\mathrm{R}$ & IM & 2 & \\
\hline & 1 & $\begin{array}{l}\text { Organization of Defensive } \\
\text { Innovation Research }\end{array}$ & FAKHRAVAC (MIVAC) & Inactivated SARS-CoV-2 & & $80-160$ & $\mathrm{R}$ & IM & 2 & \\
\hline & I & $\begin{array}{l}\text { The Scientific and Technological } \\
\text { Research Council of Turkey }\end{array}$ & Adjuvanted SARS-CoV-2 & Inactivated SARS-CoV-2 & & $80-160$ & $\mathrm{R}$ & SC & 2 & \\
\hline & 1 & Koçak Farma & Koçak-19 & Inactivated SARS-CoV-2 & & $80-160$ & $\mathrm{R}$ & IM & 2 & \\
\hline \multirow[t]{8}{*}{ DNA } & III & Zydus Cadila & ZYCoV-D & pDNA (S protein) & n.s. & $<20$ & $\mathrm{R} / \mathrm{RT}$ & ID & 3 & $\mathrm{n} / \mathrm{a}$ \\
\hline & $\|/\| I I$ & $\begin{array}{l}\text { Osaka University/Takara/ } \\
\text { AnGes }\end{array}$ & AG0301-COVID19 & pDNA (S protein) & n.s. & $<20$ & R/RT & IM & 2 & \\
\hline & $\|/\| I I$ & Inovio Pharmaceuticals & INO-4800 & pDNA (S protein) & n.s. $(+$ e.p. $)$ & $<20$ & R/RT & ID & 2 & \\
\hline & I/II & GeneOne Life Sciences & GLS-5310 & pDNA (S protein) & n.s. & $<20$ & $\mathrm{R} / \mathrm{RT}$ & ID & 2 & \\
\hline & I/II & Genexine Consortium & GX-19N & pDNA ( $\mathrm{S}+\mathrm{N}$ proteins $)$ & n.s. & $<20$ & $\mathrm{R} / \mathrm{RT}$ & IM & 2 & \\
\hline & I/II & Takis/Rottapharm Biotech & COVID-eVax & pDNA (RBD domain) & n.s. (+e.p.) & $<20$ & $\mathrm{R} / \mathrm{RT}$ & IM & $1-2$ & \\
\hline & 1 & $\begin{array}{l}\text { University of Sydney/Bionet/ } \\
\text { Technovalia }\end{array}$ & COVIGEN & pDNA (S protein) & n.s. & $<20$ & $\mathrm{R} / \mathrm{RT}$ & $\mathrm{ID} / \mathrm{IM}$ & 2 & \\
\hline & I & Providence Health and Services & CORVax12 & pDNA (S protein + IL12) & n.s. (+e.p.) & $<20$ & $\mathrm{R} / \mathrm{RT}$ & ID & 2 & \\
\hline \multirow[t]{4}{*}{ Peptide } & In use III+ & $\begin{array}{l}\text { State Research Center of } \\
\text { Virology and Biotechnology } \\
\text { (Vector) }\end{array}$ & EpiVacCorona vaccine & Peptide (S) antigens & $\begin{array}{l}\text { N/MBP carrier } \\
\text { protein }\end{array}$ & $<20$ & $\mathrm{R}$ & IM & 2 & $\mathrm{n} / \mathrm{a}$ \\
\hline & II/III & Vaxxinity & UB-612 & $\begin{array}{l}\text { Multitope S1-RBD protein/ } \\
\text { peptides }\end{array}$ & n.s. & $<20$ & $\mathrm{R}$ & IM & 2 & \\
\hline & I & University Hospital Tuebingen & IMP CoVac-1 & Peptide antigens & n.s. & $<20$ & $\mathrm{R}$ & sC & 1 & \\
\hline & 1 & OSE Immunotherapeutics & CoVepiT & Peptide antigens $(S, M, N)$ & n.s. & $<20$ & $\mathrm{R}$ & SC & 1 & \\
\hline
\end{tabular}




\section{Table 1 | Overview of all COVID-19 vaccines currently under emergency-use authorization or clinical development (Continued)}

\begin{tabular}{|c|c|c|c|c|c|c|c|c|c|c|}
\hline $\begin{array}{l}\text { Vaccine } \\
\text { vector type }\end{array}$ & $\begin{array}{l}\text { Clinical trial } \\
\text { phase }\end{array}$ & Developer(s) & Name & Biological agent (antigen) & $\begin{array}{l}\text { Nanoparticle/ } \\
\text { vector }\end{array}$ & Size $(n m)$ & $\begin{array}{l}\text { Storage/ } \\
\text { transport }\end{array}$ & $\begin{array}{l}\text { Admin. } \\
\text { method }\end{array}$ & $\begin{array}{l}\text { No. of } \\
\text { doses }\end{array}$ & $\begin{array}{l}\text { Previous } \\
\text { clinical } \\
\text { use }\end{array}$ \\
\hline \multirow[t]{25}{*}{$\begin{array}{l}\text { Protein } \\
\text { subunit }\end{array}$} & In use III+ & $\begin{array}{l}\text { Anhui Zhifei/Chinese Academy } \\
\text { of Sciences }\end{array}$ & ZF2001 & Protein subunit (RBD dimer) & n.s. & $<20$ & $\mathrm{R}$ & IM & $2-3$ & $\checkmark$ \\
\hline & In use III+ & $\begin{array}{l}\text { Center for Genetic Engineering } \\
\text { and Biotechnology }\end{array}$ & CIGB-66 & Protein subunit (RBD) & n.s. & $<20$ & $\mathrm{R}$ & IM & 3 & \\
\hline & III & Instituto Finlay de Vacunas & FINLAY-FR-2 & $\begin{array}{l}\text { Protein subunit (RBD/tetanus } \\
\text { toxoid) }\end{array}$ & n.s. & $<20$ & $\mathrm{R}$ & IM & 2 & \\
\hline & III & Sanofi Pasteur/GSK & VATO0002* & Protein subunit (S protein) & n.s. & $<20$ & $\mathrm{R}$ & IM & 2 & \\
\hline & III & $\begin{array}{l}\text { West China Hospital/Sichuan } \\
\text { University }\end{array}$ & Recombinant RBD & Protein subunit (RBD) & n.s. & $<20$ & $\mathrm{R}$ & IM & 2 & \\
\hline & III & $\begin{array}{l}\text { Nanogen Pharmaceutical } \\
\text { Biotechnology }\end{array}$ & Nanocovax & Protein subunit (S protein) & n.s. & $<20$ & $\mathrm{R}$ & IM & 2 & \\
\hline & II/III & $\begin{array}{l}\text { Clover Biopharmaceuticals/GSK/ } \\
\text { Dynavax }\end{array}$ & SCB-2019 & $\begin{array}{l}\text { Protein subunit (S protein } \\
\text { trimer) }\end{array}$ & n.s. & $<20$ & $\mathrm{R}$ & IM & 2 & \\
\hline & II & $\begin{array}{l}\text { Medigen Vaccine Biologics/ } \\
\text { Dynavax }\end{array}$ & MVC-COV1901 & Protein subunit (S protein) & n.s. & $<20$ & $\mathrm{R}$ & IM & 2 & \\
\hline & II & $\begin{array}{l}\text { Razi Vaccine and Serum Research } \\
\text { Institute }\end{array}$ & RaziCoV Pars & Protein subunit (S protein) & n.s. & $<20$ & $\mathrm{R}$ & $I M+I N$ & 3 & \\
\hline & ॥ & $\begin{array}{l}\text { Livzon/Guangdong Provincial } \\
\text { Center for Disease Control and } \\
\text { Prevention }\end{array}$ & $V-01$ & $\begin{array}{l}\text { Protein subunit (fusion } \\
\text { protein) }\end{array}$ & n.s. & $<20$ & $\mathrm{R}$ & IM & 2 & \\
\hline & II & Vaxine/CinnaGen & Covax-19 & Protein subunit (S protein) & n.s. & $<20$ & $\mathrm{R}$ & IM & $1-2$ & \\
\hline & $1 / 11$ & Instituto Finlay de Vacunas & FINLAY-FR-1 & Protein subunit (RBD dimer) & n.s. & $<20$ & $\mathrm{R}$ & IM & 2 & \\
\hline & $1 / 11$ & Biological E Ltd & BECOV2 & Protein subunit (RBD) & n.s. & $<20$ & $\mathrm{R}$ & IM & 2 & \\
\hline & $1 / 11$ & Kentucky Bioprocessing & KBP-COVID-19 & Protein subunit (RBD) & n.s. & $<20$ & $\mathrm{R}$ & IM & 2 & \\
\hline & $1 / I I$ & $\begin{array}{l}\text { Center for Genetic Engineering } \\
\text { and Biotechnology (CIGB) }\end{array}$ & CIGB-669 & Protein subunit (RBD) & n.s. & $<20$ & $\mathrm{R}$ & IN & 3 & \\
\hline & $1 / I 1$ & Shionogi & S-268019 & Protein subunit & n.s. & $<20$ & $\mathrm{R}$ & IM & 2 & \\
\hline & $1 / I I$ & $\begin{array}{l}\text { University Medical Center } \\
\text { Groningen/Akston Biosciences }\end{array}$ & AKS-452 & $\begin{array}{l}\text { Protein subunit (RBD-Fc } \\
\text { fusion) }\end{array}$ & n.s. & $<20$ & $\mathrm{R}$ & $\mathrm{SC} / \mathrm{IM}$ & n.d. & \\
\hline & $1 / 11$ & University of Saskatchewan & COVAC-1/COVAC-2 & Protein subunit (S protein) & n.s. & $<20$ & $\mathrm{R}$ & IM & 2 & \\
\hline & $1 / 11$ & EuBiologics & EuCorVac-19 & Protein subunit (S protein) & n.s. & $<20$ & $\mathrm{R}$ & IM & 2 & \\
\hline & 1 & Adimmune & AdimrSC-2f & Protein subunit (RBD) & n.s. & $<20$ & $\mathrm{R}$ & n.d. & n.d. & \\
\hline & 1 & Jiangsu Rec-Biotechnology & ReCOV & Protein subunit (S NTD/RBD) & n.s. & $<20$ & $\mathrm{R}$ & IM & 2 & \\
\hline & 1 & SK Bioscience & NBP2001 & Protein subunit (RBD) & n.s. & $<20$ & $\mathrm{R}$ & IM & 2 & \\
\hline & 1 & VaxForm & CoV2-OGEN1 & Protein subunit (RBD) & n.s. & $<20$ & $\mathrm{R}$ & Oral & $1-2$ & \\
\hline & $A b$ & Sanofi Pasteur/GSK & VAT00002** & Protein subunit (S protein) & n.s. & $<20$ & $\mathrm{R}$ & IM & 2 & \\
\hline & $A b$ & University of Queensland/Seqirus & V451/MF59 & Protein subunit (S-clamp) & n.s. & $<20$ & $\mathrm{R}$ & IM & 2 & \\
\hline Bacteria & 1 & Symvivo & bacTRL-Spike & DNA (S protein) & Bifidobacteria & $1-8 \times 10^{4}$ & RT & Oral & 1 & $\mathrm{n} / \mathrm{a}$ \\
\hline \multirow[t]{3}{*}{ Cell therapy } & $1 / 11$ & $\begin{array}{l}\text { Aivita Biomedical/NIHRD } \\
\text { Indonesia }\end{array}$ & AV-COVID-19 & $\mathrm{S}$ protein pulsed APC & APC & $>10 \times 10^{4}$ & - & IM & 1 & $\mathrm{n} / \mathrm{a}$ \\
\hline & $1 / I I$ & $\begin{array}{l}\text { Shenzhen Geno-Immune Medical } \\
\text { Institute }\end{array}$ & LV-SMENP-DC & $\begin{array}{l}\text { Synthetic minigene (viral } \\
\text { protein domains) }\end{array}$ & $\begin{array}{l}\text { LV transduced } \\
\text { APC }+T \text { cell }\end{array}$ & $>10 \times 10^{4}$ & - & $\mathrm{SC}+\mathrm{IV}$ & 1 & \\
\hline & 1 & $\begin{array}{l}\text { Shenzhen Geno-Immune Medical } \\
\text { Institute }\end{array}$ & Covid-19/aAPC & $\begin{array}{l}\text { Synthetic minigene (viral } \\
\text { protein domains) }\end{array}$ & $\begin{array}{l}\text { LV transduced } \\
\text { aAPC }\end{array}$ & $>10 \times 10^{4}$ & - & SC & 3 & \\
\hline
\end{tabular}

Vaccines currently under emergency-use authorization are listed at the top of each category. 'In use' is defined as emergency public rollout in at least one country. 'Ab' indicates trial abandoned. 'Previous clinical use' means that previously approved vaccines have used same/similar technology. Information on size, storage and dosing has been extracted from the developers' press release(s), website, clinical trial registration or publications/preprints or has been inferred based on similar/existing technologies within the same group. Some details may change as development continues. srRNA, self-replicating RNA; ts-srRNA, temperature-sensitive srRNA; S/F/N proteins, spike/fusion/nucleocapsid proteins; S-F, S protein fusion; NTD, N-terminal domain; RBD, receptor-binding domain; pDNA, plasmid DNA; IL12, interleukin 12; LNP, lipid nanoparticle; NP, nanoparticle; PLV, proteolipid vehicle; VLP, virus-like particle; pVLP, plant-derived VLP; eVLP, enveloped VLP; Ad, adenovirus; ChAd, chimpanzee Ad; GrAd, gorilla Ad; NDV, Newcastle disease virus; VSV, vesicular stomatitis virus; MVA, modified vaccinia Ankara; MV, measles virus; RSV, respiratory syncytial virus; e.p., electroporation; N/MBP, N protein/mannose binding protein; APC, antigen-presenting cell; aAPC, artificial APC; LV, lentivirus; F, frozen; R, refrigerated; RT, room temperature; L, lyophilized; IM, intramuscular; ID, intradermal; SC, subcutaneous; IN, intranasal; IV, intravenous; n.d., not determined; n.s., not specified; ${ }^{\star}$, new formulation; ${ }^{* \star}$, original formulation; \#, single product. Table based on the WHO Draft landscape and the COVID-19 Vaccine Tracker https://covid19.trackvaccines.org/vaccines/ (updated 28 July 2021).

Thomas Kisby (D) 1,2,6, Ac̦elya Yilmazer (iD)3,4,6 and Kostas Kostarelos (iD) 1,2,5凶

${ }^{1}$ Nanomedicine Lab, Faculty of Biology, Medicine \& Health, University of Manchester, Manchester, UK. ${ }^{2}$ National Graphene Institute, University of Manchester, Manchester, UK. ${ }^{3}$ Stem Cell Institute, Ankara University, Ankara, Turkey.
${ }^{4}$ Department of Biomedical Engineering, Ankara University, Ankara, Turkey. ${ }^{5}$ Catalan Institute of Nanoscience and Nanotechnology (ICN2), UAB Campus Bellaterra, Barcelona, Spain. ${ }^{6}$ These authors contributed equally: Thomas Kisby, Açelya Yilmazer.

$\varpi_{\text {e-mail: kostas.kostarelos@manchester.ac.uk }}$
Published online: 11 August 2021

https://doi.org/10.1038/s41565-021-00946-9

References

1. Wang, C., Horby, P. W., Hayden, F. G. \& Gao, G. F. Lancet 395, 470-473 (2020)

2. Jackson, L. A. et al. N. Engl. J. Med. 383, 1920-1931 (2020).

3. Mulligan, M. J. et al. Nature 586, 589-593 (2020). 
4. Kyriakidis, N. C., López-Cortés, A., González, E. V. Grimaldos, A. B. \& Prado, E. O. npj Vaccines 6, 28 (2021).

5. Walsh, E. E. et al. N. Engl. J. Med. 383, 2439-2450 (2020).

6. Polack, F. P. et al. N. Engl. J. Med. 383, 2603-2615 (2020).

7. Baden, L. R. et al. N. Engl. J. Med. 384, 403-416 (2020).

8. Pardi, N., Hogan, M. J., Porter, F. W. \& Weissman, D. Nat. Rev. Drug Discov. 17, 261-279 (2018).

9. Akinc, A. et al. Nat. Nanotechnol. 14, 1084-1087 (2019).

10. Kulkarni, J. A., Cullis, P. R. \& Van Der Meel, R. Nucleic Acid Ther 28, 146-157 (2018).

11. Moderna COVID-19 Vaccine EUA Fact Sheet for Recipients and Caregivers (FDA, 2021).

12. Pfizer-BioNTech COVID-19 Vaccine EUA Fact Sheet for Recipients and Caregivers (FDA, 2021)

13. Mui, B. L. et al. Mol. Ther. Nucleic Acids 2, el39 (2013)

14. Heyes, J., Hall, K., Tailor, V., Lenz, R. \& MacLachlan, I. J. Control Release 112, 280-290 (2006).

15. Kim, J. H., Marks, F. \& Clemens, J. D. Nat. Med. 27, 205-211 (2021).

16. Crystal, R. G. Hum. Gene Ther. 25, 3-11 (2014).

17. Singh, R. \& Kostarelos, K. Trends Biotechnol. 27, 220-229 (2009).

18. Dicks, M. D. et al. PLoS ONE 7, e40385 (2012).

19. Logunov, D. Y. et al. Lancet 397, 671-681 (2021)

20. Pollard, A. J. et al. Lancet Infect. Dis. 21, 493-506 (2020).

21. Sadoff, J. et al. N. Engl. J. Med. 384, 1824-1835 (2021).

22. Zhu, F.-C. et al. Lancet 396, 479-488 (2020).
23. Voysey, M. et al. Lancet 397, 881-891 (2021).

24. Ledford, H. Nature https://doi.org/10.1038/d41586-021-00526-w (2021).

25. Schultz, N. H. et al. N. Engl. J. Med. 384, 2124-2130 (2021).

26. Muir, K.-L., Kallam, A., Koepsell, S. A. \& Gundabolu, K. N. Engl.

J. Med. 384, 1964-1965 (2021).

27. Barouch, D. H. J. Pathol. 208, 283-289 (2006).

28. Yilmazer, A., Al-Jamal, W. T., Van den Bossche, J. \& Kostarelos, K. Biomaterials 34, 1354-1363 (2013).

29. Van den Bossche, J. et al. Biomaterials 32, 3085-3093 (2011).

30. Singh, R., Tian, B. \& Kostarelos, K. FASEB J. 22, 3389-3402 (2008).

31. Kreppel, F. \& Kochanek, S. Mol. Ther. 16, 16-29 (2008).

32. Kim, P. H., Kim, T. I., Yockman, J. W., Kim, S. W. \& Yun, C. O. Biomaterials 31, 1865-1874 (2010).

33. Sanofi \& GSK. https://www.gsk.com/en-gb/media/press-releases/ sanofi-and-gsk-announce-a-delay-in-their-adjuvantedrecombinant-protein-based-covid-19-vaccine-programme-toimprove-immune-response- in-the-elderly/ (2020).

34. Sanofi \& GSK. https://www.gsk.com/en-gb/media/press-releases/ sanofi-and-gsk-initiate-new-phase-2-study-of-their-adjuvantedrecombinant-protein-based-covid-19-vaccine-candidate/ (2021).

35. Mallapaty, S. Nature https://doi.org/10.1038/d41586-021-00094-z (2021).

36. Mahase, E. Br. Med. J. 372, n296 (2021).

37. Keech, C. et al. N. Engl. J. Med. 383, 2320-2332 (2020).
38. Poland, G. A., Ovsyannikova, I. G. \& Kennedy, R. B. Lancet 396, 14-20 (2020)

39. Kostarelos, K. Nat. Nanotechnol. 15, 343-344 (2020).

40. Editorial. Nat. Nanotechnol. 14, 1083 (2019).

41. Couvreur, P. J. Control Release 311, 319-321 (2019).

42. Park, K. J. Control. Release 305, 221-222 (2019).

\section{Acknowledgements}

T.K. and K.K. acknowledge financial support from the UK Research \& Innovation Engineering and Physical Sciences Research Council International Centre-to-Centre grant (EP/S030719/1). A.Y. thanks the Scientific and Technological Research Council of Turkey (TUBITAK, 18AG020) and the Turkish Academy of Sciences (TUBA, GEBP 2018) for financial support.

\section{Author contributions}

All authors designed the research, searched and discussed the findings in this manuscript and contributed to co-authorship of the manuscript.

Competing interests

The authors declare no competing interests.

\title{
Nanofabrication meets open science
}

\author{
Sharing the step-by-step procedures necessary to fabricate nanostructures could optimize efforts to achieve \\ reproducible devices.
}

\section{Mohammad J. Bereyhi and Tobias J. Kippenberg}

$\mathrm{T}$ he notion of 'tacit knowledge' applies to many fields of science and refers to details that are often not communicated in papers. Yet such details are essential to understand or reproduce results. One of the present authors witnessed an example first-hand: ultrahigh- $Q$ microsphere resonators seemed to appear wherever the pioneering researchers from Moscow State University spent time and taught others. Evidently, hands-on training was required to replicate their results. One area where tacit knowledge is essential is micro- and nanofabrication. Today's information society is based on technologies that interconnect optical, electrical or magnetic signals - technologies that are manufactured 'top down' by advanced nanofabrication techniques. These techniques are ubiquitous: they are widely used in many contemporary fields of research, ranging from quantum science and condensed matter physics to photonics and astronomy, to name just a few.

While open science is advancing, and sharing datasets and analysis routines is receiving rising attention, the nanofabrication details behind an experiment remain mostly unreported, and the special ingredients of each recipe are often limited to a short paragraph, usually in the methods section of a scientific article. It is fairly common to report further data, theory or analysis in the supplementary information, but rarely - if at all - the important and 'down to earth' problems of nanofabrication. Reviewers are not used to seeing, and certainly do not expect to see, such details.

In fairness, many $\mathrm{PhD}$ theses report the often long and tedious steps necessary to fabricate a device, but this knowledge is almost never communicated more broadly. As a result, although at first glance reproducing a device from the short description in a scientific article may seem straightforward, it is far from a trivial task.

This is due to the nature of the nanofabrication process. What works in a specific environment may not necessarily be reproduced in a different one. It is arguably for this reason that some researchers prefer not to communicate the process specifics. For example, removing different lithography masks after a dry etching process can leave contaminating residues. An external adhesion promoter or an internal agent inside the resist may not be simple to remove. It is well known in the micro-electromechanical systems community that removing photo-lithography masks after a reactive ion etching process requires both dry and wet cleaning steps (for instance, oxygen plasma and NMP solution). Yet this may not be known to a researcher in photonics who is removing an electron beam mask after etching a nanophotonic circuit. Although some of this knowledge can be found in textbooks, subtle details - such as how to remove specific contaminants, which developers react with which materials, and perhaps most importantly which processes fail to achieve the desired goal - are far from commonly available information, even when they can determine success or failure (Fig. 1).

It is possible in principle to reproduce the required environment and conditions for a fabrication process if sufficient information is available. For example, dimensional control using scanning electron microscope images to fabricate ultra-low-loss photonic crystal cavities is a necessity. However, how to precisely calibrate the measured values in a scanning electron microscope is neither trivial nor discussed in a publication on this 